\title{
Distinctive phenotype in a girl with Rett syndrome and a novel 25 bp deletion mutation \\ in exon 4 (c.881_905del25, nm_004992.3) of the MECP2 gene
}

\author{
Matej Katavić ${ }^{1}$, Monika Kukuruzović ${ }^{1}$, Maša Malenica', Sara Seneca², Ljerka Cvitanović-Šojat ${ }^{1}$
}

\begin{abstract}
Rett syndrome is a pervasive developmental disorder with a variable clinical presentation, which is caused by point mutations or large deletions/duplications in the X-linked methyl-CPG-binding protein 2 (MECP2) gene. The aim is to describe variation in the clinical course related to the mutation identified in exon 4 of the MECP2 gene. Retrospective review of data, electroencephalography and treatment was done in a 19-year-old girl previously diagnosed with a MECP2 gene mutation. Born after an uneventful pregnancy, the female patient's growth and psychomotor development were normal, except for delayed speech. At the age of 3 years, tonic-clonic seizures started and at the age of 3.5 years autistic behavior was observed, followed by rapid mental deterioration, loss of speech and motor skills, with periods of hyperventilation. At the age of 5 years, she showed occasionally "hand-washing" movements. Extensive neuro-metabolic investigation was nondiagnostic. Genetic analysis revealed a novel 25 bp deletion mutation in exon 4 (c.881_905del25) of the MECP2 gene. Until now, multiple epileptic seizure types, refractory to all antiepileptic polytherapy and with normal video EEG background, have occurred daily. She is spastic and ataxic, but still able to walk slowly with a wide based gait. In this female patient, the onset of symptoms manifested much later than encountered in typical cases of Rett syndrome. Epilepsy with daily frequency is however drug resistant. Unexpectedly, she is still able to walk at the age of 19 years. A genotype-phenotype correlation is suspected.
\end{abstract}

Keywords: Rett Syndrome; MECP2 protein, human; mutation; epilepsy

\section{INTRODUCTION}

Rett syndrome (RTT, MIM 312750) is a severe, progressive neurodevelopmental disorder, now classified into pervasive diseases. It is caused by mutations in the X-linked methylCpG-binding protein 2 (MECP2) gene. The syndrome is predominantly found in females, with global prevalence of approximately one per 10 000-15 000 female newborns (1). Rett syndrome can be differentiated into two types: classical and atypical. Typical or classic Rett syndrome is characterized by normal development up to the age of 7 to 18 months. A period of developmental stagnation is followed by rapid vocabulary regression, stereotypic hand move- ments, and loss of speech and acquired motor skills. In contrast, atypical Rett syndrome refers to a series of patients who do not meet all the criteria, but manifest with some variations in clinical presentation of the disease, character-

${ }^{1}$ Clinical Department of Pediatrics, Sestre milosrdnice University Hospital Center, Vinogradska cesta 29, 10000 Zagreb, Croatia

${ }^{2}$ Center for Medical Genetics, UZ Brussels, Vrije Universiteit Brussels, Laarbeeklan 101, 1090 Brussels, Belgium

\section{Correspondence to:}

Ljerka Cvitanović-Šojat, MD, PhD, Clinical Department of Pediatrics; Sestre milosrdnice University Hospital Center; Vinogradska 29, 10000 Zagreb, Croatia; e-mail: ljerka-cvitanovic.sojat@zg.t-com.hr

Primljeno/Received: 22. 9. 2014., Prihvaćeno/Accepted: 30. 9. 2014. 
ized by heterogeneity in the age of onset, severity and clinical course (2). Point mutations and insertion/deletion variations in the MECP2 gene (Xq28) are reported in approximately $70 \%-80 \%$ of classic Rett syndrome cases (3) and in a much lower percentage of atypical cases $(4,5)$. Epilepsy is considered a major problem in all Rett syndrome patients (6).

\section{CASE REPORT}

Our patient was born after an uneventful pregnancy in a family with no apparent disease history, as a fourth child. There were no complications during the perinatal period. Her growth and psychomotor development were normal, except for delayed speech. The first tonic-clonic seizure started at three years of age and were followed by developmental and language delay and deterioration. Landau-Kleffner syndrome was suspected. Because of autism-like behavior, periods of ataxia and hyperventilation with episodes of breath-holding spells, eye-rolling motions and astatic epileptic fits, multiple metabolic diseases were excluded by numerous analyses (amino and organic acids, catalytic activities of lysosomal enzymes). No signs of numerical or structural chromosomal changes were found. Electroencephalographic (EEG) records during awake and sleep periods demonstrated focal and paroxysmal discharges. Magnetic resonance imaging (MRI) of the brain was normal and without signs of demyelination. Brain auditory evoked potentials showed bilaterally conduction disturbances through the brain stem with no hearing problems. At the age of 5 years, hand-washing movements were observed, and clinical suspicion of Rett syndrome was confirmed with identification of a heterozygous novel 25 bp deletion mutation (c.881_905del25) in exon 4 of the MECP2 gene.

Multiple epileptic seizure types resistant to any drug therapy occurred on a daily basis. Antiepileptic drug therapy was started with carbamazepine, and then ethosuximide was added but was soon replaced with valproic acid. Carbamazepine was also omitted and vigabatrin was slowly introduced. Vigabatrin was discontinued and lamotrigine, shortly followed by topiramate, was introduced in therapy. Although the patient is still under this dual drug treatment to improve her EEG, she is suffering from astatic and tonic seizures every day, especially in the morning. Presently, she has a wide based gait, spastic slow walk and major problems with sleeping. There have been occasional aggression incidents.

\section{DISCUSSION}

With case description of this girl we want to emphasize how different genotypes can have atypical phenotypes. The on- set of symptoms began much later than usual. At the age of three years, she had her first seizure, while seizures commonly occur at the age of 7 to 18 months $(2,3)$. In addition, her ability to walk at the age of 19 is still preserved $(3,5)$. In most cases of Rett syndrome, patients lose their ability to walk by the age of 10 years, and have lost it certainly in their late teens $(3,5)$. Continuous seizures, often seen in other cases of Rett syndrome $(2,6-8)$, but with resistance to all combinations of antiepileptic drug therapy, is the main problem in this patient. Using standard genetic analysis (26), a novel deletion mutation was revealed in exon 4 of the MECP2 gene. The pathogenic mutations in the coding parts of the MECP2 exon 4 have previously been described as more common in Croatian girls (9).

\section{CONCLUSION}

We described a 19-year-old girl with Rett syndrome. The patient had a markedly different clinical presentation of the illness, with epileptic seizures at daily frequency and the ability to walk at the age of 19 years. She was found to be heterozygous for a novel 25 bp deletion mutation in exon 4 (c.881_905del25) of the MECP2 gene. To our knowledge, this mutation has not yet been reported. There is an important discordance between the usual progression of the illness and her current clinical state. A genotype-phenotype correlation is suspected.

\section{Abbreviations:}

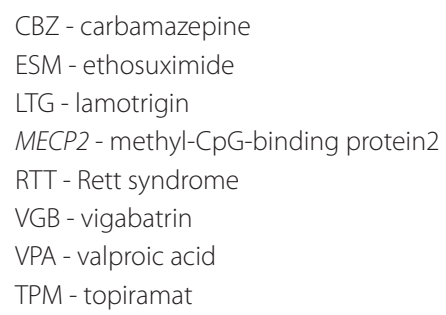

\section{NOVČANA POTPORA/FUNDING}

Nema/None

\section{ETIČKO ODOBRENJE/ETHICAL APPROVAL}

Nije potrebno/None

\section{DOPRINOSI AUTORAVDECLARATION OF AUTHORSHIP}

Svi autori jednako su doprinijeli izradi rada/All authors have equally contributed to a manuscript writing.

\section{SUKOB INTERESA/CONFLICT OF INTEREST}

Autori su popunili the Unified Competing Interest form na www.icmje.org/ coi_disclosure.pdf (dostupno na zahtjev) obrazac i izjavljuju: nemaju potporu niti jedne organizacije za objavljeni rad; nemaju financijsku potporu niti jedne organizacije koja bi mogla imati interes za objavu ovog rada u posljednje 3 godine; nemaju drugih veza ili aktivnosti koje bi mogle utjecati na objavljeni rad./All authors have completed the Unified Competing Interest form at www.icmje.org/coi_disclosure.pdf (available on request from the corresponding author) and declare: no support from any organization for the submitted work; no financial relationships with any organizations that might have 
an interest in the submitted work in the previous 3 years; no other relationships or activities that could appear to have influenced the submitted work.

\section{REFERENCES}

1. Williamson SL, Christodoulou J. Rett syndrome: new clinical and molecular insights. Eur J Hum Genet. 2006;14:896-903. http://dx.doi.org/10.1038/sj.ejhg.5201580

2. Hagberg B, Hanefeld F, Percy A, Skjeldal O. An update on clinically applicable diagnostic criteria in Rett syndrome. Comments to Rett Syndrome Clinical Criteria Consensus Panel Satellite to European Paediatric Neurology Society Meeting, Baden Baden, Germany, 11 September 2001. EJPN 2002;6:293-7.

3. Bienvenu T, Carrie A, de Roux N, et al. MECP2 mutations account for most cases of typical forms of Rett syndrome. Hum Mol Genet. 2000;9:1377-84. http://dx.doi.org/10.1093/hmg/9.9.1377

4. Zappella M, Meloni I, Longo I, et al. Study of MECP2 gene in Rett syndrome variants and autistic girls. Am J Med Genet B Neuropsychiatr Genet.
2003;119B:102-7.

http://dx.doi.org/10.1002/ajmg.b.10070

5. Gill H, Cheadle JP, Maynard J, et al. Mutation analysis in the MECP2 gene and genetic ounselling for Rett syndrome. J Med Genet. 2003;40:380-4. http://dx.doi.org/10.1136/jmg.40.5.380

6. Nissenkorn A, Gak E, Vecsler M, et al. Epilepsy in Rett syndrome - the experience of a National Rett Center. Epilepsia. 2010;51:1252-8. http://dx.doi.org/10.1111/j.1528-1167.2010.02597.x

7. Isaksen J, Bryn V, Diseth TH, et al. Children with autism spectrum disorders - The importance of medical investigations. EJPN 2013;17:68-76.

8. Cooper RA, Kerr AM, Amos PM. Rett syndrome: critical examination of clinical features, serial EEG and video-monitoring in understanding and management. EJPN 1998;2:127-38.

9. Matijević T, Knezević J, Barišić I, Rešić B, Čulić V, Pavelić J. The MECP2 gene mutation screening in Rett syndrome patients from Croatia. Ann NY Acad Sci. 2006;1091:225-32. http://dx.doi.org/10.1196/annals.1378.069

\title{
Karakterističan fenotip u djevojčice s Rettovim sindromom i delecijom 25 bp zbog nove mutacije u 4. eksonu (.881_905del25,nm_004992.3) gena MECP2
}

\author{
M. Katavić, M. Kukuruzović, M. Malenica, S. Seneca, Lj. Cvitanović-Šojat
}

Rettov sindrom (RTT) pervazivni je razvojni poremećaj s različitim kliničkim slikama, a uzrokovan najčešće točkastim mutacijama ili delecijom/duplikacijom metil-CpG-vezanog proteina 2 (MECP2) na genu X. Cilj je opisati različitosti kliničkog tijeka bolesti koje su vezane za nađenu mutaciju na 4. eksonu gena MECP2. Retrospektivna analiza anamnestičkih podataka, electroencefalograma $i$ liječenja kod 19-godišnje djevojke s nalazom mutacije na genu MECP2. Djevojčica je rođena nakon uredne trudnoće kao 4. dijete u obitelji, rast i psihomotorni razvoj su bili uredni, osim zaostatka u razvoju govora. Sa 3 godine započeli su toničko-klonički grčevi, a sa 3,5 godine uočava se autistično ponašanje, nakon čega je uslijedila mentalna deterioracija s prestankon govora, smetnjama motorike i povremenim kratkotrajnim javljanjima hiperventilacije. Sa 5 godina povremeno su se uočavali pokreti "pranja ruku”. Velikim opsegom neurometaboličkih pretraga nije se našao uzrok smetnjama. Genetičkom analizom nađena je delecija 25 bp kao jedna od novih mutacija u 4. eksonu (c.881_905del25) gena MECP2. Uslijedili su razni oblici epileptičkih napadaja koji su bili tvrdokorni na antiepileptičku terapiju, uz urednu osnovnu aktivnost na video-elektroencefalogramu. Djevojka ima povišen mišićni tonus, ataktičan hod i može samostalno hodati na širokoj osnovi. U ove djevojke simptomi su počeli kasnije nego u tipičnim slučajevima Rettovog sindroma. Epileptički napadaji su svakodnevni i tvrdokorni na terapiju, a 19-godišnja djevojka još hoda, a najvjerojatniji razlog je međusobna povezanost genotipa i fenotipa.

Ključne riječi: Rettov sindrom; MECP2 protein, humani; mutacija; epilepsija 